Både Bernhard Hvals medisinske eskapader og hans medisinske forståelse for ting er ikke mindre enn fantastisk godt gjengitt. Og legger man til det historiske aspektet ved teksten, kan jeg ikke si noe annet enn at boken er imponerende.

Lars Saabye Christensen beviser med Bernhard Hvals forsnakkelser at han er en forfatter med like mye medisinhistorisk innsikt som innlevelsesevne. Det er få norske forfattere som har en stødigere fortellerstemme.

\section{Christer Mjåset}

Nevrokirurgisk avdeling

Oslo universitetssykehus, Ullevål

\section{Hjertestarter med drapsvirus}

Anne Holt, Even Holt

Flimmer

432 s. Oslo: Piratforlaget, 2010. Pris NOK 379 ISBN 978-82-8143-262-8

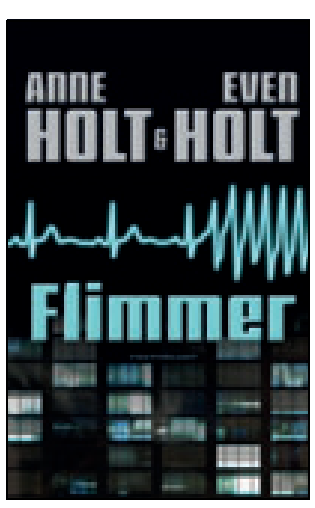

Anne Holt (f. 1958)

er en dreven krimforfatter. Hun har utgitt en rekke bøker av vekslende kvalitet. Fellesnevneren har vært aktuelle og snedige plott, mens språk og personskildringer ofte har vært flate og klisjépreget. I Flimmer har hun fått med seg broren, Even (f. 1963), som medforfatter. Han er kardiolog ved Bærum sykehus og blir behørig presentert på omslaget. Til og med årstallet for doktorgraden er med. Med broren på laget har Anne Holt forsterket den biten hun er god på selv: plottet. Hadde hun rekruttert en tredjemann med tilsvarende skjønnlitterær kompetanse, kunne dette blitt bra. Men dessverre, Flimmer er blitt en typisk Anne Holt-roman. Plottet er troverdig, personene ikke.

Handlingen utspiller seg på GRUS, Grini universitetssykehus, en hybrid av Rikshospitalet og Bærum sykehus. Her er hovedpersonen, den internasjonalt berømte kardiologen Sara Zuckerman, seksjonsoverlege. Bakgrunnen for at hun har havnet her, er selsomt konstruert.

For Sara Zuckerman tilhører toppsjiktet, hun har amerikansk statsborgerskap, er eksentrisk, arrogant og lynende begavet. $\mathrm{Og}$ - som navnet indikerer - hun er jødisk og eksotisk. «En stjerne var hun, en megastjerne, på en himmel større enn den over Norge, og Bærum ...». Nå, ja. Prosaen er i hvert fall umiskjennelig.

Boken starter med at Sara Zuckerman opererer inn en hjertestarter på sin tidligere elsker og kollega, professor emeritus Erik Berntsen. To dager senere får han hjertestans og faller død om. Noen dager senere skjer det samme med en annen tilfeldig pasient. Og en tredje unngår så vidt samme skjebne. Hjertestarteren som skulle redde liv, har fått en omvendt funksjon. Noen har plantet et virus i den implanterbare defibrillatoren (ICD) og gjort den til en drapsmaskin. Hvem er skurken? Vel. Den geniale nerden som laget programmet, er død, men etterlot seg en minnepinne. Hvem har fått tak i den, og hvorfor dukker viruset opp først mange år senere? Hvorfor i Norge? Og hvorfor i Bærum? Jo da. Plottet er spenstig.

Defibrillatoren er produsert av Mercury Medicals, et USA-basert, verdensledende firma. Selskapet er bunnsolid. Den norske stat kontrollerer $33 \%$ av eierandelene etter å ha investert svimlende 500 milliarder av oljefondet. Toppsjef og gründer av Mercury er et maskinmenneske med «tyrenakke» og «total mangel på empati». For å fjerne enhver tvil om psykopatdiagnosen er han i tillegg utstyrt med det tyskklingende navnet Otto Schultz - og alle assosiasjoner det måtte vekke. Slik punkteres spenningen, allerede før leseren er skikkelig i gang. Det hamres inn: Otto Schultz er skurken over alle skurker, uten en eneste formildende egenskap.

Sara Zuckermans våpendrager $\mathrm{i}$ kampen for å avsløre hvem som står bak de virusinfiserte defibrillatorene, er assistentlegen Ola Farmen. Som Even Holt er Ola Farmen lege og sivilingeniør fra NTH. Der stopper muligens likhetene. For Ola Farmen er en intelligent rotekopp som tøyer alle regler, i kronisk mangel på penger og søvn, fem unger med navn som begynner på $\mathrm{T}$, psykiaterkone og hus og bil i et salig kaos.

Det kryr av personer. I de første kapitlene introduserer forfatterne like mange karakterer som i en Tolstoj-roman. Det lesses på med privatliv og familiebeskrivelser, pratsomt og forutsigbart, side opp og side ned. Figurene er sjablongmessig konstruert. For endimensjonale til å bli interessante. For karikerte til å bli troverdige. Spesielt rammer dette hovedpersonen, Sara Zuckerman. Som verdensstjerne og baconspisende, bannende jøde fra Tromsø er hun uten enhver troverdighet.

Hvem vil ha glede av boken? Anne Holts trofaste lesere vil ikke bli skuffet (eller overrasket). De medisinsk interesserte kan få en grundig innføring i funksjon og implantasjon av defibrillatorer, ettersom første kapittel er skrevet nærmest som bruksanvisning og håndbok. For lesere med sans for et spenstig krimplott kan boken være bingo på en kjedelig flytur. Men det forutsetter overbærenhet med traurig brukskunstprosa og magaplaskende karakterer.

May Brit Lund

Lungeavdelingen

Oslo universitetssykehus, Rikshospitalet

\section{Roman om menneskets litenhet}

David Lodge

Deaf sentence: a novel

320 s. London: Penguin, 2009. Pris GBP 9 ISBN 9780141035703

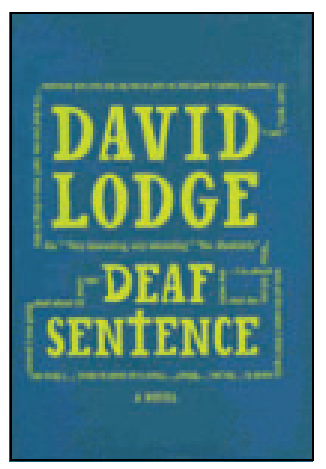

I dedikasjonen som han tilegner oversetterne av sine romaner, innrømmer David Lodge (f. 1935) at han er klar over at allerede fra tittelen av byr denne romanen på problemer. Deretter siterer han en Oxford-ordbok

som angir sju forskjellige betydninger av ordet «sentence», før vi blir konfrontert med professor Desmond Bates, en engelsk lingvist som har gått av med tidlig pensjon. Desmond Bates er svært hemmet av nedsatt hørsel, han er på det nærmeste døv. Dessuten er han sønn av en nå 89 år gammel tidligere dansemusiker som er enkemann og ikke lenger i stand til å klare seg selv. Men det vil ikke faren medgi. Og dermed er vi midt oppe i geriatriske problemstillinger med begynnende demens, vrangforestillinger, f.eks. om skattevesenets egentlig rolle, og økende prostatisme. Dette møter Desmond Bates med full tyngde. På den annen side har Desmond Bates voksne barn med problemer. Han står med sine egne vansker midt mellom to generasjoner. Samtidig kommer vi som lesere inn i den døves verden. Lodge lar oss oppleve de uforståelige samtalene med bisarre svar på hva man trodde var spørsmålet, forsøkene på å holde en daglig konversasjon gående, vel vitende om at man ikke har en anelse om hva motparten snakker om. I neste avsnitt gir han oss fasiten: hva samtalen egentlig handlet om, ved å flytte seg fra første til tredje person.

Den tunghørte professoren tar i bruk tekniske hjelpemidler, og de er til hjelp, men bare delvis. Dessuten må man alltid ha riktige batterier for hånden. $\mathrm{Og}$ apparatene er små og ikke så enkle å håndtere. Legg så til at hovedpersonen er gift med en noe yngre kvinne som har skapt seg en karriere med moteforretning. Det er duket for problemer og misforståelser. David Lodge kjenner dem alle og skriver med varme og medfølelse. Professoren savner sitt arbeid, men bare av og til. Da han blir spurt om å være veileder for en sjarmerende, ung kvinne, som frister ham slike enkelte akademikere ofte har ønsket å bli fristet, slår hans moralske integritet til, og han motstår fristelsen.

$\AA$ være blind er tragisk, men å være døv er komisk, forsikrer Lodge oss, og viser oss svært mange komiske hendelser. Beskrivelsen av kurset for å lese på munnen er 
kostelig. Men boken har flere dimensjoner og er egentlig en melankolsk beretning om menneskets litenhet. Jeg anbefaler den.

\section{Dag S. Thelle}

Avdeling for biostatistikk

Universitetet i Oslo

\section{Verdifullt om pest}

Karl-Erik Frandsen

The last plague in the Baltic region, 1709-1713

537 s, tab, ill. København: Museum Tusculanum Press, 2010. Pris DKK 475

ISBN 978-87-635-0770-7

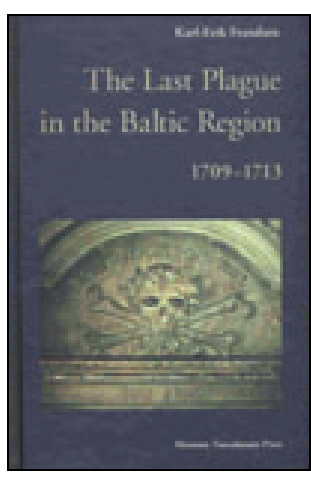

Sykdomsbetegnelsen «byllepest» får de fleste av oss til å tenke på svartedauden, denne fryktelige epidemien som kom til Sicilia og SørFrankrike midt på 1300-tallet, og som derifra spredde seg videre over hele Europa i løpet av to-tre år. Mindre kjent i dag er det kanskje at den første epidemien i Vest-Europa ble fulgt av nye utbrudd med 10-20 års mellomrom i de neste 300 årene. I Venezia er det gode holdepunkter for 26 pestepidemier frem til den siste i 1631, og i Sverige tyder kildene på 24 pestepidemier frem til den nest siste i 1653. I de fleste vesteuropeiske land fant de siste pestepidemiene sted midt på 1600tallet, f.eks. i 1654 i Christiania og mange områder på Østlandet, og i 1665 i London. Lengre øst, i Russland og i Det ottomanske riket, fortsatte imidlertid pest å være en aktuell epidemisk sykdom med regelmessige utbrudd helt frem til slutten av 1800-tallet.

I begynnelsen av 1700-tallet, under Den store nordiske krig, nådde en ny pestepidemi Polen og kystene av Østersjøen fra sydøst. Den spredde seg derifra til sørkysten av Finland og store deler av det sørøstlige Sverige, Nord-Tyskland og Sjælland. Dødeligheten var, etter vår tids målestokk, enorm. På Øland døde kanskje oppimot $50 \%$ av befolkningen. Stockholm hadde før pesten en befolkning på omkring 50 000. Ifølge kirkebøker døde 17887 mennesker av pest i løpet av fire måneder høsten 1710 , men mange døde uten å bli registrert. I København var dødeligheten enda høyere, over 22000 personer døde i løpet av fem måneder ifølge kirkebøkene. Samtidige administrative rapporter argumenterer med at de reelle dødstallene var høyere, kanskje 25 000, noe moderne historikere støtter. Befolkningen var også der trolig nær 50000 før pesten, men mange fra overklassen flyktet til andre deler av Danmark, blant andre Ludvig Holberg (1684-1754), så dødeligheten i den eksponerte befolkningen var trolig godt over $50 \%$.

Mekanismene bak spredningen av pestepidemier ble studert og diskutert helt fra den første omkring 1350. Leger var, særlig i de første århundrene, opphengt i gresk medisinsk tradisjon og argumenterte for spredning med fordervet luft (miasmer). Prester argumenterte med at epidemien var straff fra Gud, og at det derfor var lite man kunne gjøre. Lekfolk hadde tidlig en oppfatning om spredningen som likner på moderne smittelære. Venezia innførte karantenebestemmelser, og i mange områder ble epidemiene forsøkt stanset ved cordon sanitaire, altså at områder der pesten herjet, ble sperret av slik at all handel og forflytning av mennesker over grensen var forbudt. Forbudene ble regelmessig håndhevet med dødsstraff. Mot slutten av den perioden pestepidemiene herjet i vesteuropeiske land, begynte også leger å ta smittehypoteser på alvor og samlet primærdata under epidemiene. På 1600-tallet ble kirkebøker innført og offentlig statistikk etablert. For pestepidemien rundt Østersjøen i årene 1709-13 finnes derfor en lang rekke primærdata og mye bedre data enn for de tidligere pestepidemiene. Disse dataene ble til dels studert i detalj i perioden før bakteriologiens tidsalder, ofte av leger som ville forsøke å finne mekanismene bak spredningen av sykdommen. Den danske marinelegen Frederik Vilhelm Mansa (17941879) utga for eksempel i 1854 en grundig avhandling, Pesten i Helsingør og Kiøbenhavn 1710 og 1711, der han benyttet kirkebøker og mye annet arkivmateriale.

Den danske historikeren Karl-Erik Frandsen presenterer i den foreliggende boken en ny studie av pesten i Helsingør og København og områdene omkring. Særlig presenterer han et omfattende og verdifullt materiale fra pesten i Helsingør. Nesten halve boken inneholder en detaljert gjennomgang av spredningen av pesten fra hus til hus (og fra person til person) i Helsingør og landdistriktene rundt på Nord-Sjælland. For disse områdene har Frandsen brukt alle tilgjengelige arkiver, og det er mange, ikke bare kirkebøker, men også forskjellige slags skattelister, skattemanntall og alle typer offentlige dokumenter fra Danske Kancelli, i tillegg til karanteneregnskapene og regnskapene for Øresundstollen. Resultatene er presentert i et stort antall verdifulle kart og grafiske fremstillinger.

For København er fremstillingen mindre detaljert, vesentlig fordi Frandsen ikke hadde nok informasjon til å kunne koble navnene til de avdøde med gateadresser. I tillegg var kirkebøkene for de tyske menighetene ødelagt i en brann. På tross av fine diagrammer og grafer gir derfor fremstillingen når det gjelder København ikke svært mye interessant informasjon.
Frandsen trekker forbausende få generelle konklusjoner av sine detaljerte undersøkelser av pestens spredning i Helsingør. To spørsmål knyttet til tidligere tiders pestepidemier i Europa blir for tiden diskutert internasjonalt. Var pestepidemiene i middelalderen og tidlig nytid samme sykdom som moderne pest, altså forårsaket av Yersinia pestis? Var svarte rotter (Rattus rattus) en nødvendig mellomvert for smittespredningen? I forhold til begge disse spørsmålene gir undersøkelsene etter mitt syn meget gode holdepunkter for å kunne gi et endelig svar, $i$ alle fall $i$ forhold til denne ene pestepidemien. Svaret må bli JA på det første spørsmålet (1) og NEI på det andre. Slik jeg leser Frandsen, deler han disse synspunktene, men han tør ikke helt formulere seg eksplisitt.

Denne boken er en meget verdifull forskningsrapport. Imidlertid antyder tittelen og presentasjonsformen at det er en helt annen type bok. Pestepidemiens herjinger i andre land rundt Østersjøen er meget summarisk fremstilt, også for områder der vi vet at det finnes mye primærmateriale. Disse avsnittene utgjør egentlig bare en bakgrunn eller en innledning for det som egentlig er bokens tema, pestepidemien på Sjælland. Tittelen er derfor sterkt misvisende og burde heller ha vært «The last plague on Zealand» eller noe liknende.

\section{Lars Walløe}

Avdeling for fysiologi

Universitetet i Oslo

Litteratur

1. Haensch S, Bianucci R, Signoli M et al. Distinct clones of Yersinia pestis caused the Black Death. PLoS Pathogens 2010; 6 (10): e1001134.

\section{På tomgang}

Patricia Cornwell Scarpetta

471 s. Oslo: Gyldendal, 2010. Pris NOK 399 ISBN 978-82-05-39489-6

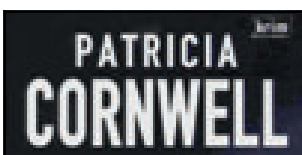

Patricia Cornwell har i mange år underholdt oss med bøkene om den utmerkede rettsmedisineren Kay Scarpetta. Det var derfor med interesse jeg så frem til den nye utgivelsen.

I denne boken, bare kalt Scarpetta har rettsmedisineren omsider giftet seg med sin mangeårige venn, rettspsykologen Wesley. Hun er også blitt kjendis gjennom programmer på TV-kanalen CNN. Niesen Lucy har også en viktig rolle som datanerd 